\title{
ONS WAS DAAR (WE WERE THERE)
}

\section{Jannie Geldenhuys (ed.)}

2011

Kraal Publishers

ISBN: 9780987025609

R340

Judging by the number of books published - either on paper or on the internet - the (probably mostly white) public's interest in the so-called Border War is ostensibly at an all-time high. By far most of the publications are written by exsoldiers who themselves participated in the war, but academics are also increasingly turning their attention in that direction.

Some of the participants simply have a story to tell, and have no ulterior motive. War is a brutal business, and putting your memories in writing is often therapeutic. However, others have a political and ideological axe to grind. They either want to "prove" that they were on the side of the angels, or that they won the war. This, by the way, also applies to some academics, who apparently find it extremely difficult to remain dispassionate when discussing the war and who are now doing everything they can to "prove" that their preferred side were the "good guys" and that the "others" were badly beaten.

It is almost as if the war is being fought all over again, although this time not with bullets or shells, but with words.

This is a pity, because these writings often obscure more than enlighten our understanding of this very important episode in the history of Southern Africa.

It was, therefore, with some anticipation that one waited for this book, which General Jannie Geldenhuys, Chief of the South African Defence Force (1985-1990), brought together. He told his own story in his memoirs ${ }^{1}$, which appeared for the first time in 1993, but he apparently felt the need to counter what he believes to be misrepresentations and lies about the SADF's role in the war more forcefully.

One cannot differ with the necessity as such. In 2007, about the time when Geldenhuys felt that he had had enough, the governing ANC came with a series of speeches, articles, seminars, even a parliamentary debate, to commemorate the

Scientia Militaria, South African Journal of Military Studies, Vol 40, Nr 1, 2012, pp. 139-143. doi: $10.5787 / 40-1-988$
SADF's alleged defeat at the Battle of Cuito Cuanavale. For instance, in a brochure published by Parliament about the commemoration, it was stated that the SADF's capture of Cuito Cuanavale would have meant 
"quite probably, also the end of Angola's existence as an independent country". It went on: "The victory at Cuito Cuanavale for the liberation forces and their Cuban compatriots was therefore decisive in consolidating Angola's independence and achieving that of Namibia." Therefore, when reflecting on the events, "it is not only the brutality of the former regime that should be recalled, but the global solidarity displayed by nations far beyond our borders, which eventually led to the fall of the apartheid regime."2

Quite apart from the question whether Parliament as an institution should distribute what amounts to the viewpoint of a political party, albeit the governing one, it was opinions like these that brought Geldenhuys to the decision that enough was enough, that he had to do something to counter it. This book is the result.

The book consists of numerous "I was there" stories. The whole spectrum of the Border War is covered, from Operation Savannah through the counterinsurgency war in Namibia to the various cross-border operations into Angola.

Some of the writers were troops or non-commissioned officers (NCO). These writings suffer from the same problem that characterises every war account at grassroots level in that the writer looks at "his" war, so to speak, through a keyhole. He sees what is immediately in front of him and is unable to furnish a perspective on the broader picture. This is not meant negatively, because there is simply no way in which a private or corporal (or even a lieutenant) can know which factors are driving the generals and colonels whose decisions influence his life.

At the same time, the writers convey a significant picture of what happened at grassroots level. War is, after all, much more than the pushing around of battalions or brigades on a map like pawns on a chessboard. War induces intense fear, heroism, boredom, physical endurance, monotonous food, dirt, horrible sights and smells, intense heat, thousands of flies, post-traumatic stress and nightmares. Many of the contributions in this book tell something about that. Moreover, they often make the same point one encounters in other similar accounts about other wars: if you were not there, you will never really understand how it was and how it affected people.

It forces anyone who was not there to be humble when judging the war.

The participants also clearly want to make sense of what happened there. They need to emphasise that their suffering was not for nothing, that they did something good, and that they won. They need to feel proud of what they did. Understandably. The accounts may not only be useful to the military historian, but also to the psychologist studying the aftermath of war on participants.

It is a pity that all these "thumbnail pictures" are never properly integrated into an over-arching history of the war. However, given the fragmentary nature of these kinds of contributions, it could not have been otherwise. 
The main purpose of the book however is political and ideological. Above all, Geldenhuys wants to counter the propaganda emanating from the ANC and Cuba.

The reviewer has a certain understanding and even sympathy with this objective. Political propaganda is not known for its truthfulness, even when it is repeated by academics who should know better.

Against this background, the book is complemented throughout by a series of viewpoints by either Geldenhuys himself or other senior officers near to the decision-making process at the time. Unfortunately, this is where the book exhibits certain deficiencies.

First of all, it is important to recall the Dutch historian Pieter Geyl's famous adage that history is a discussion without end. Depending on the available facts, and on the angle from where one looks at them, differing conclusions may be reached. That is natural and even desirable. However, there is a - vague - line that one should probably try not to cross. That is when an analysis calls up the phrase "the lady doth protest too much".

It would probably have been better if Geldenhuys had written only one piece to enunciate his take on the war. As it is, his contributions are scattered throughout the book. He repeats himself time and again, and unfortunately "doth protest too much". In the process, he lashes out at just about everyone who does not agree $120 \%$ with his views. These targets are not simply, as one might expect, those who say that the SADF lost its "immoral" war, but even people like FW de Klerk, Pik Botha, Professor Hermann Giliomee, Dr Van Zyl Slabbert, and others.

Geldenhuys even commissioned a chapter by the late Brigadier-General JNR ("Junior") Botha, harshly attacking this reviewer for an academic article published in $1998 .^{3}$ This was apparently because the article's conclusions (somewhat critical of the SADF leadership's operational decisions) depended - according to Botha - too much on military writers like Carl von Clausewitz and BH Liddell Hart. (Which probably makes me the wrong person to review the book, but I shall refrain from commenting any further on Botha, who has died and cannot defend himself here.)

Just one observation: Botha and several other contributors repeatedly denied that there was a "Battle of Cuito Cuanavale". This is based on the - in itself correct - contention that the SADF never really wanted to occupy the village. An alternative name for the battle (or campaign, if you prefer that) is not proposed. However, this does not mean that the name of Cuito Cuanavale cannot be coupled to the battle. In military history, battles more often than not take their name from a nearby village or town, even though the place itself never became the stage where the fighting took place. It appears that Botha and the other authors again "doth protest too much". There is nothing wrong with referring to the "Battle of Cuito Cuanavale". This, of 
course, does not excuse the falsification of history by the ANC, Parliament, Cuba or politically correct academics.

Geldenhuys repeatedly makes the point that the SADF's war in Angola contributed to the USSR's downfall. There is no doubt that the war played a role, but one gets the impression that he exaggerates this fact. The perspective that other factors, such as the Afghan War, the military spending race with the USA, the USSR's economic implosion - and, most importantly, the fall of the Berlin Wall were decisive, is however missing. Angola added some weight, but could never have brought down the Colossus on its own.

Geldenhuys apparently also has his own (political) axe to grind. He makes several disparaging remarks about how things went wrong after FW de Klerk took over from PW Botha, how the SANDF went downhill after 1994, and so on. Of course, as a South African citizen, this is his constitutional right, and one would never presume to deny him that. Nevertheless, one wonders whether a book like this is the right place for this.

When trying to make a contribution to our historical knowledge and understanding, it undermines one's credibility if you take the opportunity to score political points of your own. In that case, it would be better to be upfront and write a political article or book. Historical writing and present-day politics do not mix well, something left-wing critics of the SADF's role do not understand either.

In the end, having read the book, one is left with a somewhat unfulfilled feeling. There is no doubt that most of the contributions by troops, NCOs and officers are very useful sources for the academic historian. The lay reader, who simply wants to get a feeling of the war at grassroots level, who wants to know how it felt or who wants to relive his own experiences, will enjoy the book. Geldenhuys did all these people a definite service.

Unfortunately, our understanding of the war is not enhanced by the political agendas of Geldenhuys and others, as witnessed by their "analyses". I do not question these people's sincerity. I do question, however, whether they did not merely serve their own purpose, which was to put the record straight. A pity, because they let an excellent opportunity slip by.

Leopold Scholtz, Military Historian, European correspondent of the Media24 newspapers and Research Fellow in the Department of History at the University of Stellenbosch. 


\section{Endnotes}

${ }^{1}$ Geldenhuys, J. Dié wat wen: 'n Generaal se storie uit 'n era van oorlog en vrede. Pretoria: Van Schaik, 1993. The English edition is At the front: A general's account of the Border War. Johannesburg: Jonathan Ball, 2009.

${ }^{2}$ Commemorating the $20^{\text {th }}$ Anniversary of the Battle of Cuito Cuanavale, Project Synopsis, n.d., n.p.

${ }^{3}$ Scholtz, L. "Cuito Cuanavale: Wie het werklik gewen?" Scientia Militaria 28/1. 1998. 16-61. 